\title{
Antitumor platinum(IV) derivatives of carboplatin and the histone deacetylase inhibitor 4-phenylbutyric acid
}

\author{
Awatif Rashed Z. Almotairy ${ }^{\mathrm{a}}$, Valentina Gandin ${ }^{\mathrm{b}}$, Liam Morrison ${ }^{\mathrm{c}}$, Cristina Marzano ${ }^{\mathrm{b}}$, \\ Diego Montagner ${ }^{\mathrm{d}, *}$, Andrea Erxleben ${ }^{\mathrm{a}, *}$ \\ a School of Chemistry, National University of Ireland, Galway, Ireland \\ b Department of Pharmaceutical and Pharmacological Sciences, University of Padova, Padova, Italy \\ c Earth and Ocean Sciences, School of Natural Sciences and Ryan Institute, National University of Ireland, Galway, Ireland \\ d Department of Chemistry, Maynooth University, Ireland
}

\section{A R T I C L E I N F O}

\section{Keywords:}

Anticancer

Carboplatin

Histone deacetylase inhibitor

4-Phenylbutyric acid

Platinum(IV)

\begin{abstract}
A B S T R A C T
Five new platinum(IV) derivatives of carboplatin each incorporating the histone deacetylase inhibitor 4-phenylbutyrate in axial position were synthesized and characterized by ${ }^{1} \mathrm{H}$ and ${ }^{195} \mathrm{Pt}$ NMR spectroscopy, electrospray ionization mass spectrometry and elemental analysis, namely cis,trans-[Pt(CBDCA) $\left.\left(\mathrm{NH}_{3}\right)_{2}(\mathrm{PBA})(\mathrm{OH})\right](\mathbf{1})$, cis,trans-[Pt(CBDCA) $\left.\left(\mathrm{NH}_{3}\right)_{2}(\mathrm{PBA})_{2}\right] \quad(2), \quad$ cis,trans-[Pt $\left.(\mathrm{CBDCA})\left(\mathrm{NH}_{3}\right)_{2}(\mathrm{PBA})(\mathrm{bz})\right] \quad(3), \quad$ cis,trans-[Pt(CBDCA) $\left.\left(\mathrm{NH}_{3}\right)_{2}(\mathrm{PBA})(\mathrm{suc})\right]$ (4) and cis,trans-[Pt(CBDCA)( $\left.\left.\left.\mathrm{NH}_{3}\right)_{2}\right)(\mathrm{PBA})(\mathrm{ac})\right](5)(\mathrm{PBA}=4$-phenylbutyrate, $\mathrm{CBDCA}=1,1-$ cyclobutane dicarboxylate, $\mathrm{bz}=$ benzoate, suc $=$ succinate and $\mathrm{ac}=$ acetate). The reduction behavior in the presence of ascorbic acid was studied by high performance liquid chromatography. The cytotoxicity against a panel of human tumor cell lines, histone deacetylase (HDAC) inhibitory activity, cellular accumulation and the ability to induce apoptosis were evaluated. The most effective complex, compound $\mathbf{3}$, was found to be up to ten times more effective than carboplatin and to decrease cellular basal HDAC activity by approximately $18 \%$ in A431 human cervical cancer cells.
\end{abstract}

\section{Introduction}

Platinum(IV) prodrugs are Pt(IV) complexes that on intracellular reduction release the axial ligands and the active square-planar platinum(II) species. Thus, conjugating a biologically active ligand to one or both axial positions of a platinum(IV) derivative of an anticancer platinum(II) drug is widely studied as a strategy for dual-action agents that target two distinct and/or independent cellular mechanisms [1]. Prominent examples are the Pt(IV) analogs of cisplatin ethacraplatin $[2,3]$, chalcoplatin [4], aplatin [5,6] and mitaplatin [7] with the glutathione-S-transferase inhibitor ethacrynic acid, a chalcone derivative acting as a p53 inhibitor, the COX inhibitor acetylsalicylate and the apoptosis sensitizer dichloroacetate in axial position, respectively (Fig. 1). Furthermore, phosphatase $2 \mathrm{~A}$ inhibitors [8], the vitamin $\mathrm{E}$ analog $\alpha$-tocopheryl succinate [9], carbohydrates [10,11], nucleotide excision repair inhibitors [12], alkylating agents [13] as well as redox modulators [14] have been attached to the cisplatin and oxaliplatin scaffold.

Carboplatin (cis-diammine-1,1-cyclobutanedicarboxylatoplatinum (II)), a second generation platinum(II) drug used in the treatment of ovarian cancer, retinoblastomas, neuroblastomas, nephroblastomas, brain, head and neck, cervical, testicular, breast, lung and bladder cancers, shows a more favorable toxicity profile compared to cisplatin and is generally better tolerated [15]. The chelating dicarboxylate leaving group is hydrolyzed more slowly than the monodentate chlorido ligands in cisplatin, thus reducing off-target binding to biomolecules prior to DNA coordination. Platinum(IV) complexes based on carboplatin have been synthesized with various biologically inactive axial ligands and their pharmacokinetic properties and structure-activity relationship have been studied [16-20]. A Pt(IV) prodrug of carboplatin has also been modified with a polymeric nanodelivery carrier [21]. However, to the best of our knowledge, in contrast to dualaction prodrugs of cis- and oxaliplatin, platinum(IV) complexes with bioactive ligands attached to the carboplatin platform seem to have remained unexplored so far.

Histone deacetylase inhibitors (HDACi) are known to enhance the effect of DNA damaging agents [22]. Belinostat, for example, reverses platinum resistance in platinum-resistant lung cancer cells when coadministered with cisplatin [23] and Trichostatin A has an additive effect with oxaliplatin in gastric tumor cells [24]. Histone deacetylase

\footnotetext{
* Corresponding authors.

E-mail addresses: Diego.Montagner@nuim.ie (D. Montagner), andrea.erxleben@nuigalway.ie (A. Erxleben).
} 
Ethacraplatin

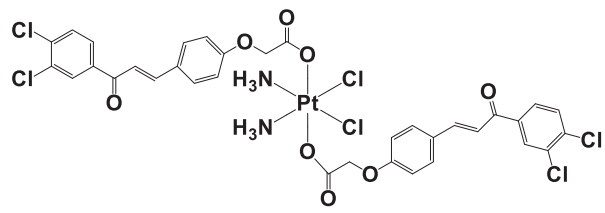

Chalcoplatin

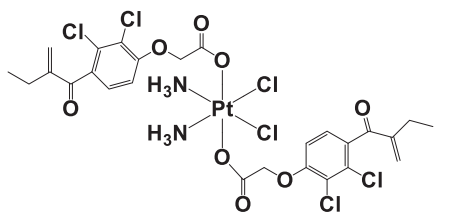

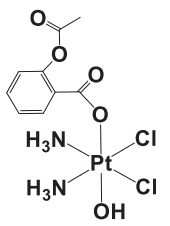

Aplatin

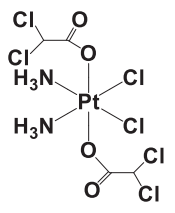

Mitaplatin
Fig. 1. Examples for dual-action anticancer Pt(IV) complexes reported in the literature.

(HDAC) regulates chromatin structure and transcription [25]. Its inhibition induces hyperacetylation of histone proteins around which DNA coils, making DNA more accessible within chromatin [26]. HDACi have also been shown to interact with non-histone proteins, including proteins that play a key role in cellular proliferation, migration, cell death, DNA repair, immune response, angiogenesis and inflammation [27]. Several HDACi are effective anticancer agents and have entered clinical trials [28]. They generally have few adverse effects on healthy cells.

Marmion and coworkers developed platinum(II) complexes with HDAC inhibitory ligands. They reported enhanced selectivity for cisplatin complexes of functionalized suberoylanilide hydroxamic acid $[29,30]$ and belinostat [31] and enhanced cytotoxicity of transplatin complexes of valproate compared to cisplatin [32]. Brabec and coworkers studied platinum(IV) prodrugs of oxaliplatin with axial valproate ligands [33]. While displaying lower cytotoxicity than oxaliplatin in cell culture, the complexes showed enhanced accumulation in tumor cells and were active in cisplatin-resistant cells. The platinum(IV) complex cis,cis,trans- $\left.\left[\mathrm{Pt}\left(\mathrm{NH}_{3}\right)_{2} \mathrm{Cl}_{2} \text { (valproate) }\right)_{2}\right]$ was shown to exert significant cytotoxicity in a range of human carcinoma cell lines, including malignant pleural mesothelioma cells [34-36]. A larger fraction of total platinum taken up by cells was found to bind to DNA, when platinum(IV) complexes containing biologically active axial ligands were used compared to platinum(IV) complexes with biologically inactive axial ligands [34]. Kasparkova et al. recently reported a photoactivatable platinum(IV) complex with axial suberoylanilide hydroxamic acid ligands [37]. Gibson and coworkers attached the HDACi 4phenylbutyric acid (PBA) and valproate to the axial positions of Pt(IV) derivatives of cisplatin and oxaliplatin [38,39]. Cis,trans,cis-[Pt $\left.\left(\mathrm{NH}_{3}\right)_{2}(\mathrm{PBA})_{2} \mathrm{Cl}_{2}\right]$ was found to be up to 100 -fold more potent than cisplatin [38]. Inhibition of HDAC activity by $60-70 \%$ in cancer cells at concentrations lower than the $\mathrm{IC}_{50}$ value of PBA suggested a synergism between platinum and PBA.

The apparent lack of studies on the functionalization of platinum (IV) derivatives of carboplatin with bioactive ligands prompted us to prepare platinum(IV) complexes with HDAC inhibitory ligands based on the carboplatin scaffold. Here we report the synthesis, characterization, cytotoxicity and HDAC inhibitory activity of a series of platinum(IV) prodrugs of carboplatin with PBA as an axial ligand.

\section{Experimental}

\subsection{Materials and methods}

Reactions were performed under normal atmospheric conditions using as-received analytical or HPLC grade solvents and reagents from commercial suppliers. $\mathrm{K}_{2} \mathrm{PtCl}_{4}$ was purchased from Acros Organics, 4- phenylbutyric acid, acetic anhydride and succinic anhydride were obtained from Sigma-Aldrich and benzoic acid, $N$-hydroxysuccinimide and dicyclohexylcarbodiimide from TCI Europe. The ultra-pure water used was purified with a Milli-Q UV purification system. Carboplatin and oxo-carboplatin (trans, cis-[Pt(CBDCA) $\left.(\mathrm{OH})_{2}\left(\mathrm{NH}_{3}\right)_{2}\right]$ ) were synthesized according to the previously reported procedures [40].

\subsection{Syntheses}

\subsubsection{NHS ester of 4-phenylbutyric acid}

4-Phenylbutyric acid $(2.0 \mathrm{~g}, 12.2 \mathrm{mmol})$ and $N$-hydroxysuccinimide $(1.4 \mathrm{~g}, 12.2 \mathrm{mmol})$ were dissolved in tetrahydrofuran $(20 \mathrm{~mL})$, followed by dropwise addition of a solution of dicyclohexylcarbodiimide $(2.5 \mathrm{~g}$, $12.2 \mathrm{mmol})$ in tetrahydrofuran $(12 \mathrm{~mL})$. The mixture was stirred at room temperature for $7 \mathrm{~h}$ and then filtered to remove the dicyclohexylurea precipitate. The filtrate was concentrated under reduced pressure. The residue was dissolved in ethyl acetate $(60 \mathrm{~mL})$ and left at $4{ }^{\circ} \mathrm{C}$ overnight. After filtration to remove the insoluble residue the organic phase was washed with $\mathrm{NaHCO}_{3}$ solution $(6 \%, 120 \mathrm{~mL})$ and water $(60 \mathrm{~mL})$ and dried over $\mathrm{Na}_{2} \mathrm{SO}_{4}$. Petroleum ether $(60 \mathrm{~mL})$ was then added to the ethyl acetate solution to precipitate the 4-PBA-NHS ester which was filtered off, washed with petroleum ether, dried, and purified by column chromatography (silica gel; 9:1 petroleum ether:ethyl acetate). Yield: $3.1 \mathrm{~g}(96 \%) ;{ }^{1} \mathrm{H}$ NMR $\left(500 \mathrm{MHz}, \mathrm{CDCl}_{3}\right): \delta 1.93-2.01$ (m, $2 \mathrm{H}, \mathrm{CH}_{2} \mathrm{CH}_{2} \mathrm{CH}_{2}$ ), 2.58 (t, $J=7.5 \mathrm{~Hz}, 2 \mathrm{H}, \mathrm{CH}_{2} \mathrm{CH}_{2} \mathrm{CH}_{2}$ ), 2.73 (t, $J=7.4 \mathrm{~Hz}, 2 \mathrm{H}, \mathrm{CH}_{2} \mathrm{CH}_{2} \mathrm{CH}_{2}$ ), 2.80 (s, 4H, $\mathrm{COCH}_{2} \mathrm{CH}_{2} \mathrm{CO}$ ), 7.20-7.29 (m, $5 \mathrm{H}, \mathrm{H}_{\mathrm{ar}}$ ); ESI-MS: $m / z=261[\mathrm{M}-\mathrm{H}]^{-}$.

\subsection{2. cis, trans-[Pt $\left.(\mathrm{CBDCA})\left(\mathrm{NH}_{3}\right)_{2}(\mathrm{PBA})(\mathrm{OH})\right]$ (1)}

The 4-PBA-NHS ester $(87.2 \mathrm{mg}, 0.34 \mathrm{mmol})$ was added to cis,trans[Pt(CBDCA) $\left(\mathrm{NH}_{3}\right)_{2}(\mathrm{OH})_{2}$ ] $(150 \mathrm{mg}, 0.37 \mathrm{mmol})$ in dimethyl sulfoxide $(17 \mathrm{~mL})$ and the mixture was stirred for $48 \mathrm{~h}$ at $65^{\circ} \mathrm{C}$. Unreacted cis,trans- $\left[\mathrm{Pt}(\mathrm{CBDCA})\left(\mathrm{NH}_{3}\right)_{2}(\mathrm{OH})_{2}\right]$ was removed by filtration, the solvent was evaporated using a freeze-dryer and the residue was dissolved in dimethylformamide $(4 \mathrm{~mL})$, followed by precipitation of the desired product with diethyl ether. The precipitate was isolated by centrifugation, washed several times with dichloromethane $(2 \mathrm{~mL})$ and diethyl ether $(20 \mathrm{~mL})$ and dried under vacuum. Yield: $144 \mathrm{mg}(71 \%)$. Anal. Calcd (\%) for $\mathrm{C}_{16} \mathrm{H}_{24} \mathrm{~N}_{2} \mathrm{O}_{7} \mathrm{Pt}$ (551.45): C, 34.84; H, 4.35; N, 5.08. Found: C, 34.63; H, 4.28; N, 5.09. ${ }^{1} \mathrm{H}$ NMR (DMSO- $d_{6}, 500 \mathrm{MHz}$ ): $\delta$ 1.6-1.7 (m, 4H, $\mathrm{CCH}_{2} \mathrm{CH}_{2}, \mathrm{CBDCA}$ and $\left.\mathrm{CH}_{2} \mathrm{CH}_{2} \mathrm{CH}_{2}, \mathrm{PBA}\right), 2.13$ (t, $J=7.4 \mathrm{~Hz}, 2 \mathrm{H}, \mathrm{CH}_{2} \mathrm{CH}_{2} \mathrm{CH}_{2}$ ), 2.42 (t, $J=8.1 \mathrm{~Hz}, 2 \mathrm{H}, \mathrm{CCH}_{2} \mathrm{CH}_{2}$, CBDCA), 2.56 (m, 4H, $\mathrm{CCH}_{2} \mathrm{CH}_{2}, \mathrm{CBDCA}, \mathrm{CH}_{2} \mathrm{CH}_{2} \mathrm{CH}_{2}, \mathrm{PBA}$ ), 5.97 (m, br., $\left.6 \mathrm{H}, \mathrm{NH}_{3}\right), 7.13-7.25\left(\mathrm{~m}, 5 \mathrm{H}, \mathrm{H}_{\mathrm{ar}}\right) ;{ }^{195} \mathrm{Pt}\left\{{ }^{1} \mathrm{H}\right\}$ NMR $(107.6 \mathrm{MHz}$, $\mathrm{DMF} / \mathrm{D}_{2} \mathrm{O}$ ): $\delta 1741$ (quin, $J_{\mathrm{PtN}}=322 \mathrm{~Hz}$ ). ESI-MS: $m / z=550.45 .0[\mathrm{M}-$ $\mathrm{H}]^{-}$.

\subsection{3. cis, trans- $\left[\mathrm{Pt}(\mathrm{CBDCA})\left(\mathrm{NH}_{3}\right)_{2}(\mathrm{PBA})\right] \cdot 0.5 \mathrm{H}_{2} \mathrm{O}$ (2)}

The 4-PBA-NHS ester $(1.546 \mathrm{~g}, 5.9 \mathrm{mmol})$ was added to cis,trans-[Pt (CBDCA) $\left.\left(\mathrm{NH}_{3}\right)_{2}(\mathrm{OH})_{2}\right](120 \mathrm{mg}, 0.29 \mathrm{mmol})$ in dimethyl sulfoxide $(20 \mathrm{~mL})$. After stirring for $72 \mathrm{~h}$ at $80{ }^{\circ} \mathrm{C}$ the mixture was concentrated to a $2 \mathrm{~mL}$ volume and the desired product was precipitated by addition of water $(20 \mathrm{~mL})$. The solid was isolated by centrifugation, washed several times with dichloromethane $(4 \mathrm{~mL})$ and diethyl ether $(40 \mathrm{~mL})$ to remove excess ligand and dried under vacuum. Yield: $130 \mathrm{mg}$ (64\%). Anal. Calcd (\%) for $\mathrm{C}_{26} \mathrm{H}_{35} \mathrm{~N}_{2} \mathrm{O}_{8.5} \mathrm{Pt}$ (706.66): C, 44.19; H, 4.99; N, 3.96. Found: C, 44.18; H, 4.85; N, 4.01. ${ }^{1} \mathrm{H}$ NMR (DMSO- $d_{6}, 500 \mathrm{MHz}$ ): $\delta$ 1.6-1.7 (m, $\left.2 \mathrm{H}, \mathrm{CH}_{2} \mathrm{CH}_{2} \mathrm{CH}_{2}, \mathrm{PBA}\right), 1.8$ (m, $2 \mathrm{H}, \mathrm{CCH}_{2} \mathrm{CH}_{2}, \mathrm{CBDCA}$ ), $2.18\left(\mathrm{t}, J=7.4 \mathrm{~Hz}, 2 \mathrm{H}, \mathrm{CH}_{2} \mathrm{CH}_{2} \mathrm{CH}_{2}\right), 2.43(\mathrm{t}, J=8.1 \mathrm{~Hz}, 2 \mathrm{H}$, $\mathrm{CCH}_{2} \mathrm{CH}_{2}, \mathrm{CBDCA}$ ), $2.50\left(\mathrm{t}, J=7.4 \mathrm{~Hz}, 2 \mathrm{H}, \mathrm{CH}_{2} \mathrm{CH}_{2} \mathrm{CH}_{2}\right), 2.64(\mathrm{t}$, $J=8.0 \mathrm{~Hz}, 2 \mathrm{H}, \mathrm{CCH}_{2} \mathrm{CH}_{2}, \mathrm{CBDCA}$ ), 6.34 (m, br., $6 \mathrm{H}, \mathrm{NH}_{3}$ ), 7.19-7.29 (m, 10H, $\mathrm{H}_{\mathrm{ar}}$ ); ${ }^{195} \mathrm{Pt}\left\{{ }^{1} \mathrm{H}\right\} \mathrm{NMR}\left(107.6 \mathrm{MHz}, \mathrm{DMF} / \mathrm{D}_{2} \mathrm{O}\right): \delta 1929$ (quin, $\left.J_{\mathrm{PtN}}=215 \mathrm{~Hz}\right)$. ESI-MS: $m / z=696.15[\mathrm{M}-\mathrm{H}]^{-}$. 


\subsection{4. cis,trans- $\left[\mathrm{Pt}(\mathrm{CBDCA})\left(\mathrm{NH}_{3}\right)_{2}(\mathrm{PBA})(\mathrm{bz})\right]$ (3) and cis, trans- $[\mathrm{Pt}$ (CBDCA) $\left.\left(\mathrm{NH}_{3}\right)_{2}(\mathrm{PBA})(\mathrm{suc})\right]$ (4)}

The unsymmetrically substituted complexes 3 and 4 were synthesized by reaction of $\mathbf{1}$ with the respective carboxylic acid anhydride. Complex 1 and 10 equivalents benzoic or succinic acid anhydride were suspended in dimethylformamide and the mixture was stirred for $2 \mathrm{~d}$ at $80^{\circ} \mathrm{C}$. The solution was concentrated under reduced pressure and diethyl ether $(40 \mathrm{~mL})$ was added to precipitate the desired product which was isolated by centrifugation and washed with dichloromethane $(4 \mathrm{~mL})$ and diethyl ether $(4 \mathrm{~mL})$ to remove residual dimethylformamide.

Complex 3: Yield: $100 \mathrm{mg}$ (61\%) from 1 (140 mg, $0.25 \mathrm{mmol})$ and benzoic anhydride ( $574 \mathrm{mg}, 2.5 \mathrm{mmol}$ ) in $20 \mathrm{~mL}$ dimethylformamide. Anal. Calcd (\%) for: $\mathrm{C}_{23} \mathrm{H}_{28} \mathrm{~N}_{2} \mathrm{O}_{8} \mathrm{Pt}$ (655.56): C, 42.14; H, 4.31; N, 4.27. Found: C, 42.01; H, 4.11; N, 4.09. ${ }^{1} \mathrm{H}$ NMR (DMSO- $d_{6}, 500 \mathrm{MHz}$ ): $\delta$ 1.7-1.8 (m, 4H, $\mathrm{CCH}_{2} \mathrm{CH}_{2}$, CBDCA and $\left.\mathrm{CH}_{2} \mathrm{CH}_{2} \mathrm{CH}_{2}, \mathrm{PBA}\right), 2.22(\mathrm{t}$, $\left.J=7.4 \mathrm{~Hz}, 2 \mathrm{H}, \mathrm{CH}_{2} \mathrm{CH}_{2} \mathrm{CH}_{2}\right), 2.45\left(\mathrm{~m}, 2 \mathrm{H}, \mathrm{CH}_{2} \mathrm{CH}_{2} \mathrm{CH}_{2}\right), 2.53(\mathrm{t}$, $J=8.0 \mathrm{~Hz}, 4 \mathrm{H}, \mathrm{CCH}_{2} \mathrm{CH}_{2}, \mathrm{CBDCA}$ ), 6.4 (m, br., $6 \mathrm{H}, \mathrm{NH}_{3}$ ), 7.10-7.23 (m, 5H, $\left.\mathrm{H}_{\mathrm{ar}}, \mathrm{PBA}\right), 7.37$ (t, $J=8.0,2 \mathrm{H}, \mathrm{H}_{\mathrm{ar}}$ ), $7.46\left(\mathrm{t}, J=8.0,1 \mathrm{H}, \mathrm{H}_{\mathrm{ar}}\right.$ ), 7.85 (d, $\left.J=6.9 \mathrm{~Hz}, 2 \mathrm{H}, \mathrm{H}_{\mathrm{ar}}\right) ;{ }^{195} \mathrm{Pt}\left\{{ }^{1} \mathrm{H}\right\} \mathrm{NMR}\left(107.6 \mathrm{MHz}, \mathrm{DMF} / \mathrm{D}_{2} \mathrm{O}\right)$ : $\delta 1931$ (quin, $J_{\mathrm{PtN}}=206 \mathrm{~Hz}$ ). ESI-MS: $m / z=654.14[\mathrm{M}-\mathrm{H}]^{-}$.

Complex 4: Yield: $90 \mathrm{mg}(77 \%)$ from $1(100 \mathrm{mg}, 0.18 \mathrm{mmol})$ and succinic anhydride ( $181 \mathrm{mg}, 0.81 \mathrm{mmol}$ ) in $20 \mathrm{~mL}$ dimethylformamide. Anal. Calcd (\%) for: $\mathrm{C}_{20} \mathrm{H}_{28} \mathrm{~N}_{2} \mathrm{O}_{10} \mathrm{Pt}$ (651.53): C, 36.87; H, 4.33; N, 4.30. Found: C, 36.74; $\mathrm{H}, 4.23$; N, 4.20. ${ }^{1} \mathrm{H}$ NMR (DMSO- $d_{6}, 500 \mathrm{MHz}$ ): $\delta$ 1.7-1.8 (m, 4H, $\mathrm{CCH}_{2} \mathrm{CH}_{2}$, CBDCA and $\mathrm{CH}_{2} \mathrm{CH}_{2} \mathrm{CH}_{2}, \mathrm{PBA}$ ), 2.20 (t, $\left.J=7.4 \mathrm{~Hz}, \quad 2 \mathrm{H}, \quad \mathrm{CH}_{2} \mathrm{CH}_{2} \mathrm{CH}_{2}\right), 2.32-2.59\left(\mathrm{~m}, 10 \mathrm{H}, \mathrm{CH}_{2} \mathrm{CH}_{2} \mathrm{CH}_{2}\right.$, $\mathrm{CCH}_{2} \mathrm{CH}_{2}$, CBDCA, $\mathrm{CH}_{2}$, suc), 6.3 (m, br., $6 \mathrm{H}, \mathrm{NH}_{3}$ ), 7.13-7.24 (m, 5H, $\left.\mathrm{H}_{\mathrm{ar}}\right) ;{ }^{195} \mathrm{Pt}\left\{{ }^{1} \mathrm{H}\right\} \quad \mathrm{NMR} \quad\left(107.6 \mathrm{MHz}, \mathrm{DMF} / \mathrm{D}_{2} \mathrm{O}\right): \delta 1934$ (quin, $J_{\mathrm{PtN}}=210 \mathrm{~Hz}$ ). ESI-MS: $m / z=650.52[\mathrm{M}-\mathrm{H}]^{-}$.

\subsection{5. cis, trans- $\left.\left[\mathrm{Pt}(\mathrm{CBDCA})\left(\mathrm{NH}_{3}\right)_{2}\right)(\mathrm{PBA})(\mathrm{ac})\right]$ (5)}

Complex 1 ( $56 \mathrm{mg}, 0.10 \mathrm{mmol}$ ) was stirred for $20 \mathrm{~h}$ in acetic anhydride ( $5 \mathrm{~mL}$ ) at room temperature. The mixture was then lyophilized and washed with diethyl ether $(2 \times 5 \mathrm{~mL})$ to isolate the desired product. Yield: $35 \mathrm{mg}(60 \%)$. Anal. Calcd (\%) for $\mathrm{C}_{18} \mathrm{H}_{26} \mathrm{~N}_{2} \mathrm{O}_{8} \mathrm{Pt}$ (593.13): C, 36.43; H, 4.42; N, 4.72. Found: C, 36.34; H, 4.36; N, 4.60. ${ }^{1} \mathrm{H}$ NMR (DMSO- $\left.d_{6}, 500 \mathrm{MHz}\right): \delta 1.7-1.8\left(\mathrm{~m}, 4 \mathrm{H}, \mathrm{CCH}_{2} \mathrm{CH}_{2}, \mathrm{CBDCA}\right.$ and $\mathrm{CH}_{2} \mathrm{CH}_{2} \mathrm{CH}_{2}, \mathrm{PBA}$ ), 1.96 (s, $3 \mathrm{H}, \mathrm{CH}_{3} \mathrm{COO}$ ), 2.20 (t, $J=7.4 \mathrm{~Hz}, 2 \mathrm{H}$, $\mathrm{CH}_{2} \mathrm{CH}_{2} \mathrm{CH}_{2}$ ), 2.4-2.6 (m, 6H, $\mathrm{CH}_{2} \mathrm{CH}_{2} \mathrm{CH}_{2}, \mathrm{PBA}, \mathrm{CCH}_{2} \mathrm{CH}_{2}, \mathrm{CBDCA}$ ), 6.3 (m, br., $6 \mathrm{H}, \mathrm{NH}_{3}$ ), 7.11-7.24 (m, 5H, $\left.\mathrm{H}_{\mathrm{ar}}\right) ;{ }^{195} \mathrm{Pt}\left\{{ }^{1} \mathrm{H}\right\} \mathrm{NMR}$ $\left(107.6 \mathrm{MHz}, \mathrm{DMF} / \mathrm{D}_{2} \mathrm{O}\right.$ ): $\delta 1935$ (quin, $J_{\mathrm{PtN}}=208 \mathrm{~Hz}$ ). $\mathrm{m} / z=592.17$ $[\mathrm{M}-\mathrm{H}]^{-}$.

\subsection{Measurements and instrumentation}

${ }^{1} \mathrm{H},{ }^{13} \mathrm{C}$ and ${ }^{195} \mathrm{Pt}$ NMR spectra were acquired with a Varian $500 \mathrm{AR}$ spectrometer. Chemical shifts are given in parts per million (ppm) with tetramethylsilane as the reference $\left(\delta\left({ }^{1} \mathrm{H}\right.\right.$ NMR $\left.)=0 \mathrm{ppm}\right)$. Coupling constants $(J)$ are given in Hertz $(\mathrm{Hz}) .{ }^{195} \mathrm{Pt}$ NMR spectra were acquired in dimethylformamide with an inserted tube containing $\mathrm{D}_{2} \mathrm{O} . \mathrm{K}_{2} \mathrm{PtCl}_{6}$ in $\mathrm{D}_{2} \mathrm{O}$ was used as an external reference. Mass spectra were obtained with a Waters LCT Premiere XE with electron spray ionization and time of flight mass analyzer. Elemental analyses (carbon, nitrogen and hydrogen) were carried out with a PerkinElmer 2400 series II analyzer.

Platinum concentrations were determined using inductively coupled plasma mass spectrometry (ICP-MS, ELAN DRCe, PerkinElmer, Waltham, USA) in a Class 1000 cleanroom [41-44]. Instrumental operating conditions included: ICP RF Power $1150 \mathrm{~W}$ : plasma gas flow $15 \mathrm{~L} \mathrm{~min}^{-1}$; auxiliary gas flow $1 \mathrm{~L} \mathrm{~min}^{-1}$; nebuliser gas flow $0.93 \mathrm{~L} \mathrm{~min}{ }^{-1}$; observed isotopes; ${ }^{192} \mathrm{Pt},{ }^{194} \mathrm{Pt},{ }^{195} \mathrm{Pt}$, ${ }^{196} \mathrm{Pt}$ and ${ }^{198} \mathrm{Pt}$. Platinum calibration standards were prepared using a single element Pt standard (SPEX CertiPrep, $1000 \mu \mathrm{g} / \mathrm{mL})$ and Milli- ${ }^{\mathrm{TM}}$ water $(18.3 \mathrm{~m} \Omega$ ) (Millipore, Bedford, USA) with $1 \% \mathrm{HNO}_{3}$ (Trace Metal Grade, 67-69\%, Fisher, UK). Iridium $\left({ }^{191} \mathrm{Ir}\right)$ and indium $\left({ }^{115} \mathrm{In}\right)$ were used as internal standards to account for instrumental drift and matrix effects.

\subsection{Reduction of the Pt(IV) complexes}

The reduction of complexes 1,2 and 3 was monitored by high performance liquid chromatography (HPLC) using an Agilent 1200 series DAD analytical HPLC instrument. The compounds were dissolved in $0.5 \mathrm{~mL}$ dimethylformamide, added to a $7 \mathrm{mM}$ solution of ascorbic acid in $4 \mathrm{mM}$ 4-(2-hydroxyethyl)piperazine-1-ethanesulfonic acid (HEPES) buffer ( $\mathrm{pH} 7)$ and diluted with acetonitrile to a final concentration of $0.5 \mathrm{mM}$. The reduction was monitored at $37{ }^{\circ} \mathrm{C}$ until completion. The samples were analyzed using a Phenomenex Luna C18 column $(5 \mu \mathrm{m}, 100 \AA, 250 \mathrm{~mm} \times 4.60 \mathrm{~mm}$ i.d.). The mobile phase was 90:10 acetonitrile ( $1 \%$ trifluoroacetic acid):water ( $1 \%$ trifluoroacetic

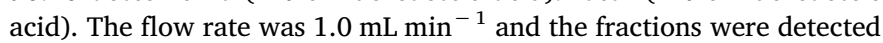
at $254 \mathrm{~nm}$.

\subsection{Determination of lipophilicity}

Octanol-water partition coefficients ( $\log P_{o / w}$ ) of the Pt(IV) compounds were determined by the shake flask method [45]. All experiments were done in duplicate. The respective Pt(IV) complex was mixed with $0.9 \% \mathrm{NaCl}(w / v)$ in ultrapure water that was presaturated with $\mathrm{n}$ octanol for $3 \mathrm{~d}$. All solutions were sonicated and filtered to remove undissolved $\mathrm{Pt}(\mathrm{IV})$ compound. The initial $\mathrm{Pt}$ concentrations were measured by ICP-MS (ELAN DRCe, Perkin Elmer, Waltham, USA) as described above. Subsequently, the Pt(IV) solution was added to an equal volume of n-octanol that was presaturated with $0.9 \% \mathrm{NaCl}(\mathrm{w} / \mathrm{v})$ in ultrapure water. The heterogeneous mixture was shaken vigorously for $1 \mathrm{~h}$ before centrifuging at $4400 \mathrm{rpm}$ for $1 \mathrm{~h}$ to achieve phase separation. The final Pt concentration in the aqueous phase was measured again by ICP-MS. $\log P_{o / w}$ values were calculated as the ratio of $\mathrm{Pt}$ concentrations in the organic and aqueous phases.

\subsection{Experiments with cultured human cells}

The Pt(IV) complexes and the corresponding uncoordinated ligands were dissolved in dimethyl sulfoxide just before the experiment and a calculated amount of drug solution was added to the cell growth medium to a final solvent concentration of $0.5 \%$, which had no detectable effect on cell killing. Cisplatin and carboplatin were dissolved in $0.9 \%$ sodium chloride solution. MTT (3-(4,5-dimethylthiazol-2-yl)2,5-diphenyltetrazolium bromide), carboplatin and cisplatin were obtained from Sigma Chemical Co, St. Louis, USA.

\subsection{Cell cultures}

The human pancreatic (BxPC3) and colon (LoVo) carcinoma and melanoma (A375) cell lines were obtained from American Type Culture Collection (ATCC, Rockville, MD). The human squamous cervical cancer cell line (A431) was kindly provided by Prof. G. Zunino (Division of Experimental Oncology B, Istituto Nazionale dei Tumori, Milan, Italy).

Cell lines were maintained in the logarithmic phase at $37{ }^{\circ} \mathrm{C}$ in a $5 \%$ carbon dioxide atmosphere using the following culture media containing $10 \%$ fetal calf serum (Euroclone, Milan, Italy), antibiotics (50 units/mL penicillin and $50 \mu \mathrm{g} / \mathrm{mL}$ streptomycin), and $2 \mathrm{mM} \mathrm{L-glu-}$ tamine: (i) RPMI-1640 medium (Euroclone) for BxPC3 and A431 cells; (ii) DMEM for A375 cells; (iii) F-12 HAM'S (Sigma Chemical Co.) for LoVo cells.

\subsection{MTT assay}

The growth inhibitory effect toward tumor cells was evaluated by means of MTT assay. Briefly, (3-8) $\times 10^{3}$ cells/well, dependent upon the growth characteristics of the cell line, were seeded in 96-well microplates in growth medium $(100 \mu \mathrm{L})$. After $24 \mathrm{~h}$, the medium was removed and replaced with fresh medium containing the compound to be 
studied at the appropriate concentration. Triplicate cultures were established for each treatment. After $72 \mathrm{~h}$, each well was treated with $10 \mu \mathrm{L}$ of a $5 \mathrm{mg} / \mathrm{mL}$ MTT saline solution and following $5 \mathrm{~h}$ of incubation, $100 \mu \mathrm{L}$ of a sodium dodecylsulfate (SDS) solution in $\mathrm{HCl}(0.01 \mathrm{M})$ was added. After an overnight incubation, cell growth inhibition was detected by measuring the absorbance of each well at $570 \mathrm{~nm}$ using a Bio-Rad 680 microplate reader. The mean absorbance for each drug dose was expressed as a percentage of the untreated control well absorbance and plotted vs. drug concentration. IC $_{50}$ values, the drug concentrations that reduce the mean absorbance at $570 \mathrm{~nm}$ to $50 \%$ of those in the untreated control wells, were calculated by a four parameter logistic (4-PL) model. All of the values are the means \pm SD of not less than five independent experiments.

\subsection{Cellular accumulation}

A431 cells $\left(2 \times 10^{6}\right)$ were seeded in $75 \mathrm{~cm}^{2}$ flasks in growth medium $(20 \mathrm{~mL})$. After overnight incubation, the medium was replaced and the cells were treated with the tested compounds for $24 \mathrm{~h}$. Cell monolayers were washed twice with cold PBS, harvested and counted. Samples were subjected to three freezing/thawing cycles at $-80{ }^{\circ} \mathrm{C}$ and then vigorously vortexed. The samples were treated with highly pure nitric acid (Pt: $\leq 0.01 \mu \mathrm{g} \mathrm{kg}^{-1}$, TraceSELECT ${ }^{\circledR}$ Ultra, Sigma Chemical Co.) and transferred into a microwave teflon vessel. Subsequently, samples were submitted to standard procedures using a speed wave MWS-3 Berghof instrument (Eningen, Germany). After cooling, each mineralized sample was analyzed for platinum by using a Varian AA Duo graphite furnace atomic absorption spectrometer (Varian, Palo Alto, CA; USA) at the wavelength of $324 \mathrm{~nm}$. The calibration curve was obtained using known concentrations of standard solutions purchased from Sigma Chemical Co.

\subsection{Histone deacetylase assay}

Histone deacetylase activity was determined using Fluor-deLys ${ }^{\circledR}$ HDAC fluorometric activity assay kit (Enzo Life Sciences International, Inc., Plymount Meeting, PA, U.S.A.). A431 cells $\left(5 \times 10^{4}\right.$ seeded in 96-well microplates) were treated for $24 \mathrm{~h}$ with $5 \mu \mathrm{M}$ tested complexes, then processed as reported by the manufacturer's instructions. Fluorescence was measured using a Fluoroskan Ascent FL (Labsystem, Finland) plate reader, with excitation at $360 \mathrm{~nm}$ and emission at $460 \mathrm{~nm}$.

\subsection{Hoechst 33258 staining}

A431 cells were seeded into 8-well tissue-culture slides (BD Falcon, Bedford, MA, USA) at $5 \times 10^{4}$ cells/well $\left(0.8 \mathrm{~cm}^{2}\right)$. After $24 \mathrm{~h}$, the cells were washed twice with PBS and following $48 \mathrm{~h}$ of treatment with $\mathrm{IC}_{50}$ concentration of tested complexes, the cells were stained for $5 \mathrm{~min}$ with $1 \mathrm{mg} / \mathrm{mL}$ Hoechst 33258 (Sigma-Aldrich) in PBS before being examined by fluorescence microscopy (Olympus BX41, Cell F software, Olympus, Munster, Germany).

\section{Results and discussion}

\subsection{Synthesis and characterization}

The chemical structures of the Pt(IV) complexes investigated in this paper are depicted in Scheme 1. The dihydroxoplatinum(IV) derivative of carboplatin (A) was obtained by oxidation of carboplatin with $\mathrm{H}_{2} \mathrm{O}_{2}$ in aqueous solution. The mono-substituted complex 1 could be synthesized by reaction of the activated NHS-ester of PBA (see experimental) and A (0.9:1 ratio) in dimethyl sulfoxide at $65^{\circ} \mathrm{C}$ with a yield of $71 \%$. The bis-substituted complex $\mathbf{2}$ was isolated after reaction of $\mathbf{A}$ with a large excess of the activated NHS-ester of PBA. All the other complexes were synthesized by reaction of the mono-PBA complex 1 with the corresponding anhydride (benzoic anhydride, 3; succinic anhydride, 4 and acetic anhydride, 5) in dimethylformamide with yields in the range of $49-75 \%$ (Scheme 1). Each complex was characterized by ESI-mass spectrometry, ${ }^{1} \mathrm{H}$ and ${ }^{195} \mathrm{Pt}$ NMR spectroscopy and the purity was assessed by elemental analysis and HPLC. The ${ }^{1} \mathrm{H}$ NMR spectra in DMSO- $d_{6}$ displayed the typical signal of the $\mathrm{NH}_{3}$ protons of the carboplatin scaffold as a broad multiplet around $6 \mathrm{ppm}$ in the case of mono-substituted 1 and as a broad signal around $6.5 \mathrm{ppm}$ in the case of the bis-substituted complexes 2-5 (Supplementary Figs. S1 - S5). The ${ }^{195} \mathrm{Pt}$ NMR spectra of the bis-substituted complexes (Supplementary Figs. S6 - S10) showed a quintet around $1900 \mathrm{ppm}$ while 1 gave a quintet at $1741 \mathrm{ppm}$ in line with chemical shift data previously reported for related Pt(IV) complexes [14]. The appearance of the signals as quintets is due to spin-to-spin coupling between ${ }^{195} \mathrm{Pt}$ and two ${ }^{14} \mathrm{~N}$ nuclei. The mass spectra of the complexes displayed a peak in the negative mode with the typical platinum isotope pattern corresponding to the respective $[\mathrm{M}-\mathrm{H}]^{-}$species (Supplementary Figs. S11 - S15).

The different axial carboxylate ligands tune the lipophilicity of the complexes; the $\log P_{o / w}$ values, determined for each complex using the shake flask method, are reported in Scheme 1 and indicate the order of lipophilicity as $\mathbf{2}>\mathbf{3}>\mathbf{5}>\mathbf{1}>\mathbf{4}$ as expected. Pt(IV) complexes enter the cell by passive diffusion and the lipophilicity index plays a major role in cellular Pt accumulation [34]. The mechanism of action of $\mathrm{Pt}(\mathrm{IV})$ complexes has been investigated in detail. The most important step is the reduction of the complexes inside the cell environment to produce the active $\mathrm{Pt}(\mathrm{II})$ species (carboplatin in this case) with the release of the axial ligands [46] and the pharmacological profiles of $\mathrm{Pt}$ (IV) complexes are greatly affected by their redox behavior. High reduction rates might lead to high systemic toxicity and to deactivation of the resulting Pt(II) form before the DNA is reached, whereas particularly low reduction rates might result in the absence of antitumor activity. While no direct correlation between the reduction potential and prodrug efficacy has been established in the literature, a reduction potential in the mid-range as observed for complexes with two axial carboxylate ligands $(\sim-600 \mathrm{mV})$ seems to be a good guideline for an effective Pt(IV) prodrug [1]. The reduction of Pt(IV) complexes has been investigated in the past with different techniques and under different conditions [47-51]. It is generally presumed that under physiological conditions $\mathrm{Pt}(\mathrm{IV})$ is reduced by low-molecular-weight reducing agents such as ascorbic acid or glutathione, although recently evidence has been obtained that higher molecular weight biomolecules such as metallothioneines can also play a major role in the reduction and activation of Pt(IV) prodrugs [52]. Until recently the reduction rate - and thus the biological activity - was assumed to directly correlate with the $\mathrm{Pt}(\mathrm{IV}) / \mathrm{Pt}(\mathrm{II})$ redox potential. The latter is mainly determined by the nature of the axial ligands. The redox potentials of Pt(IV) complexes of general formula cis,trans, cis- $\left[\mathrm{PtCl}_{2} \mathrm{~L}_{2}(\mathrm{Am})_{2}\right]$ decrease in the order $\mathrm{L}=\mathrm{OH}^{-} \quad(\sim-900 \mathrm{mV})<\mathrm{RCOO}^{-} \quad(\sim-600 \mathrm{mV})<\mathrm{Cl}^{-}$ $(\sim-250 \mathrm{mV})$ [53]. Some exceptions have recently been reported where the reduction rate does not correlate with the redox potential of the Pt(IV) complex. In particular, it was found that mono-substituted species with one axial $\mathrm{OH}$ group are reduced faster than bis-carboxylated complexes due to the ability of the $\mathrm{OH}$ group to act as a bridging ligands in an inner-sphere electron transfer mechanism [54,55]. In summary, it is quite hard to predict and estimate the reduction rate of a $\mathrm{Pt}(\mathrm{IV})$ complex, as many factors may come into play (e.g. Pt(II) scaffold, nature of the axial ligands, reducing agent) $[56,57]$. The reduction with ascorbic acid and the release of the PBA ligands under physiological conditions $\left(37^{\circ} \mathrm{C}, \mathrm{pH} 7\right)$ of the monocarboxylated complex 1 , the bisPBA complex $\mathbf{2}$ and $\mathbf{3}$ as a representative of the mixed carboxylic acid complexes, was monitored by HPLC (Fig. 2 and Supplementary Figs. S16 and S17). Comparison of the HPLC chromatograms obtained during the reduction reaction with that of the pure PBA ligand confirmed that the reduction of $\mathrm{Pt}(\mathrm{IV})$ to $\mathrm{Pt}(\mathrm{II})$ leads to the release of the axial ligands. Incubation with 10 eq. of ascorbic acid for $5 \mathrm{~h}$ resulted in the reduction of $75 \%$ of complex 2 and $50 \%$ of complex 3 . The complexes were 


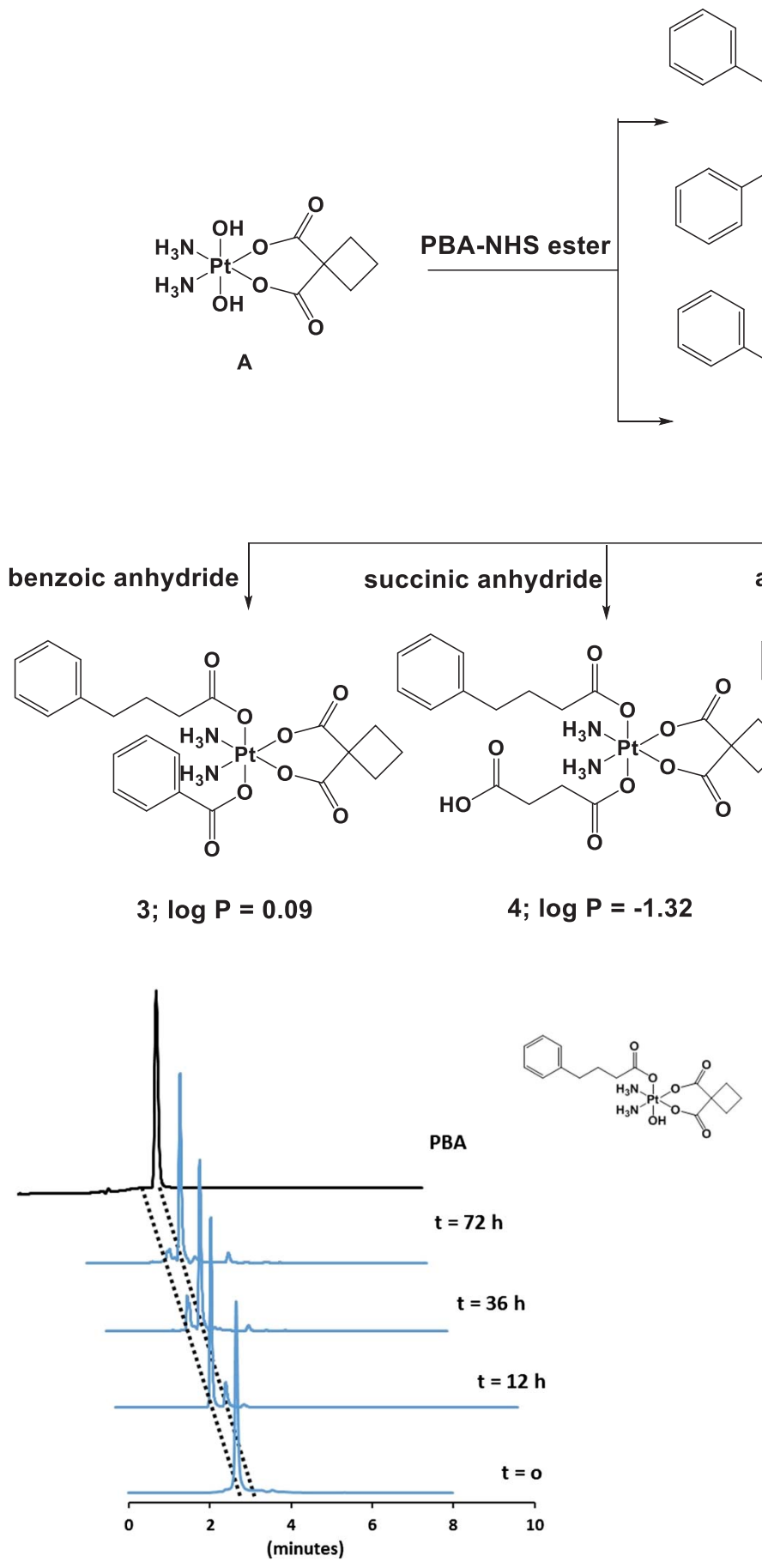

Fig. 2. HPLC chromatogram of the reaction of 1 with 10 eq. ascorbic acid at $37^{\circ} \mathrm{C}$ and $\mathrm{pH}$ 7. The chromatogram of the free ligand PBA is shown for comparison purposes.

reduced completely after $12 \mathrm{~h}(2), 36 \mathrm{~h} \mathrm{(3)}$ and $72 \mathrm{~h}(\mathbf{1})$. Noteworthy, for the reduction of complex 3 both released axial ligands (PBA and benzoic acid) could be identified in the chromatogram.

\subsection{Cytotoxicity}

The ability of the Pt(IV) complexes 1-5 to promote cell death was evaluated in several human cancer cell lines derived from solid tumors (A431 cervical, LoVo colon, BxPC3 pancreatic and A375 melanoma cells). The cytotoxicity parameters, in terms of IC $_{50}$ values obtained after $72 \mathrm{~h}$ of exposure to the MTT assay, are listed in Table 1. For comparison purposes, the cytotoxicities of cisplatin and carboplatin
Scheme 1. Synthesis of the Pt(IV) complexes 1-5.

Table 1

$\mathrm{IC}_{50}$ values of 1-5 in different cancer cell lines ${ }^{\mathrm{a}}$.

\begin{tabular}{lllll}
\hline \multicolumn{5}{l}{ IC $50(\mu \mathrm{M}) \pm$ S.D. } \\
\cline { 2 - 5 } & A375 & BxPC3 & LoVo & A431 \\
\hline $\mathbf{1}$ & $18.5 \pm 5.9$ & $36.2 \pm 8.3$ & $13.5 \pm 3.9$ & $16.8 \pm 3.6$ \\
$\mathbf{2}$ & $16.6 \pm 3.5$ & $24.2 \pm 3.2$ & $13.5 \pm 2.5$ & $15.9 \pm 3.7$ \\
$\mathbf{3}$ & $11.1 \pm 2.9$ & $6.2 \pm 0.3$ & $5.1 \pm 1.3$ & $5 \pm 2$ \\
$\mathbf{4}$ & $24.2 \pm 3.5$ & $36.3 \pm 3.2$ & $18.4 \pm 2.9$ & $19.7 \pm 5.1$ \\
$\mathbf{5}$ & $23.3 \pm 6.2$ & $34.6 \pm 3.1$ & $39.3 \pm 4.2$ & $25.3 \pm 2.3$ \\
Carboplatin & $13.5 \pm 3.0$ & $30.9 \pm 4.2$ & $49.3 \pm 7.1$ & $12.3 \pm 3.3$ \\
PBA & $39.4 \pm 4.1$ & $1523 \pm 36$ & $1075 \pm 44$ & $1115 \pm 31$ \\
Cisplatin & $3.3 \pm 1.0$ & $11.1 \pm 1.7$ & $9.1 \pm 2.1$ & $1.7 \pm 0.3$ \\
\hline
\end{tabular}

a Cells $\left(3-5 \times 10^{4} \mathrm{~mL}^{-1}\right)$ were treated for $72 \mathrm{~h}$ with increasing concentrations of the tested compounds. The cytotoxicity was assessed by the MTT test. IC So $_{5}$ values were calculated by a four parameter logistic model $(\mathrm{P}<0.05)$. S.D. = standard deviation.

were assessed under the same experimental conditions. Cancer cell lines included in the screen were endowed with different degrees of sensitivity to cisplatin and carboplatin and showed a good concentrationdependent response to treatment with the newly synthesized complexes. The uncoordinated HDACi ligand PBA displayed very low cytotoxic activities, with $\mathrm{IC}_{50}$ values mainly in the millimolar range, in agreement with the literature [38].

Complexes 1-4 were found to be more effective than the reference metallodrug carboplatin, but only derivative 3 possessed an in vitro antitumor activity comparable to that of cisplatin, with the average $\mathrm{IC}_{50}$ values being 6.8 and $6.0 \mu \mathrm{M}$ for 3 and cisplatin, respectively. Actually, 3 emerged as the most cytotoxic derivative, eliciting mean IC $_{50}$ values from 3- to 5-fold lower than those calculated for the other complexes of the series. It is noteworthy that complex 3 was roughly 1.8 -fold more effective than cisplatin against human BxPC3 pancreatic and LoVo colon cancer cells and on average 5 and 10 times more effective than carboplatin. 


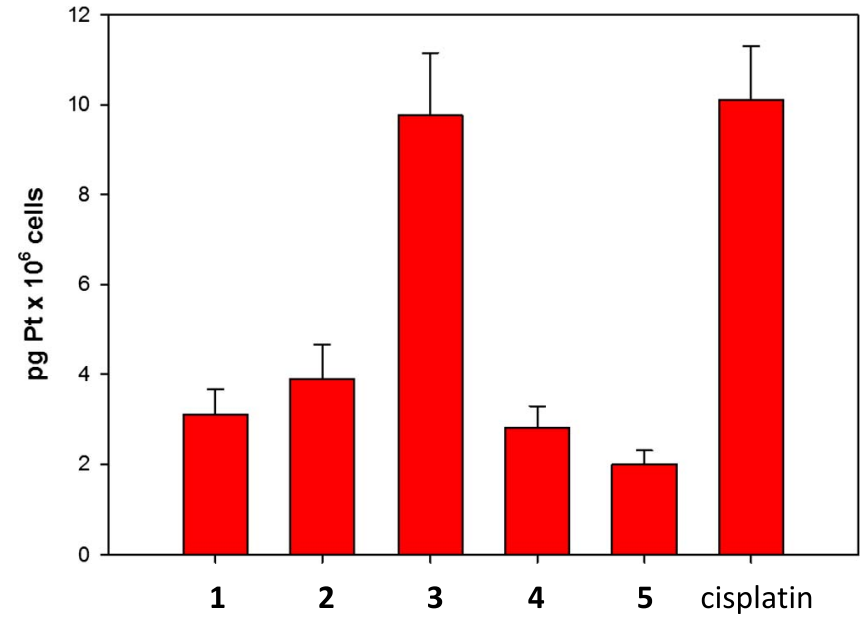

Fig. 3. Cellular accumulation of 1-5 and cisplatin into A431 cervical cancer cells. A431 cells were incubated for $24 \mathrm{~h}$ with the complexes at 3.125 and $6.25 \mu \mathrm{M}$ concentrations. The intracellular platinum content was determined by GF-AAS.

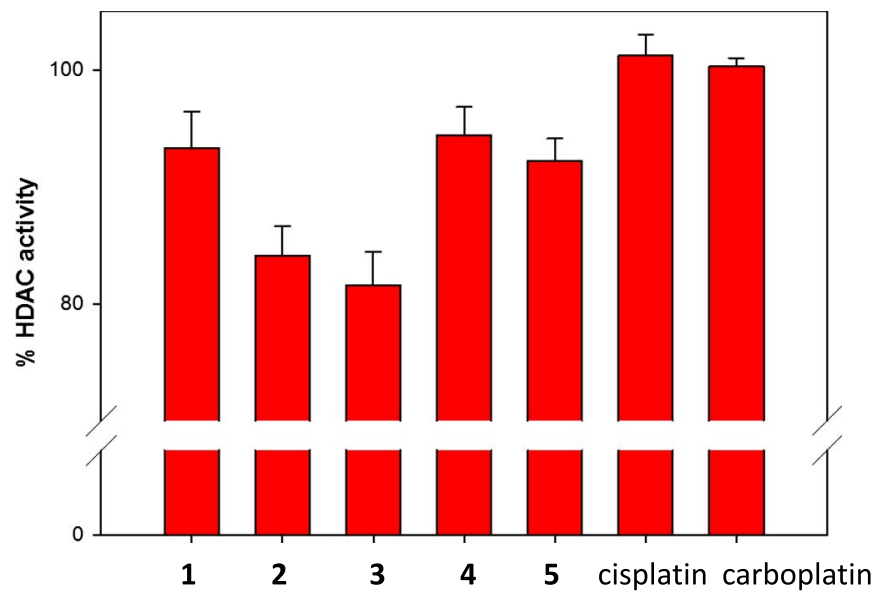

Fig. 4. Effects on HDAC activity induced by $\mathbf{1 - 5}$, cisplatin and carboplatin in A431 cervical cancer cells. A431 cells were incubated for $24 \mathrm{~h}$ with the complexes at $5 \mu \mathrm{M}$ concentration. The HDAC activity was determined by FLUOR DE LYS ${ }^{\circledR}$ HDAC fluorometric activity assay kit (Enzo Life Sciences).

\subsection{Platinum cellular accumulation}

In an attempt to correlate the cytotoxic activity with cellular accumulation, the platinum content was evaluated in A431 cells treated for $24 \mathrm{~h}$ with 3.125 and $6.25 \mu \mathrm{M}$ solutions of the Pt(IV)-complexes. The intracellular platinum amount was quantified by means of GF-AAS analysis and the results, expressed as pg metal per $10^{6}$ cells, are shown in Fig. 3. Although to a different extent, all complexes accumulated proportionally to drug concentration into A431 cancer cells. The cellular accumulation of $\mathbf{3}$ was greater compared to that of the other derivatives in the series and was comparable to that of cisplatin at both tested concentrations. These results allow us to correlate the cytotoxic activity with the ability of the Pt(IV) complexes to enter and accumulate into cancer cells. Interestingly, there is no correlation between lipophilicity and cellular internalization. Although this is somewhat unexpected, since, unlike Pt(II) complexes, Pt(IV) complexes are believed to enter cells solely by passive diffusion, a similar lack of correlation between $\log P$ values and cellular Pt accumulation has been reported for other Pt(IV) systems $[14,38,58,59]$.

\subsection{HDAC inhibition}

As the newly synthesized complexes described here were designed to release the PBA moiety after reduction once inside the cells, we measured the ability of these prodrugs to inhibit HDAC activity in cells. A431 cells were incubated for $24 \mathrm{~h}$ with cytotoxic concentrations of the tested compounds $(5 \mu \mathrm{M})$ and their HDAC activity was determined. The trend of HDAC inhibition resembles that obtained in the cytotoxicity studies. As expected, cisplatin and carboplatin were not effective in modifying HDAC activity (Fig. 4). Among all, compound 3 was the most effective in hampering HDAC activity, being able to decrease the cellular basal activity by roughly $18 \%$.

\subsection{Induction of apoptosis}

To gain more insight into the mode of action of the newly synthesized Pt(IV) complexes, we evaluated the capacity of the most effective derivative 3 to induce apoptosis in human cervical cancer cells. In particular, apoptotic cell death induction was confirmed through a Hoechst 33342 staining assay. Fig. 5 shows Hoechst 33342 stained A431 cells after $48 \mathrm{~h}$ treatment with $\mathrm{IC}_{50}$ concentrations of 3 or carboplatin. For both, compound $\mathbf{3}$ and carboplatin, treated cells as compared with untreated cells, displayed chromatin condensation and fragmentation as well as pyknotic nuclei, typical features of apoptosis.

\section{Conclusions}

A new series of Pt(IV) complexes based on the carboplatin scaffold and the HDAC inhibitor PBA as an axial ligand has been synthesized, characterized and tested on a panel of four different cancer cell lines. The lower cytotoxic activity with respect to the reference drug cisplatin is not unexpected and has been previously seen in other carboplatin derivatives since carboplatin in general requires a higher dose to show a significant anticancer activity [40]. Platinum accumulation studies revealed that complex $\mathbf{3}$ shows an intracellular accumulation comparable with that of cisplatin and indeed it possesses the highest cytotoxic activity and HDAC inhibition potency. Lower accumulation levels and consequently a lower cytotoxicity was observed for the other complexes. The slow reduction kinetics of the Pt(IV) prodrugs of carboplatin should also contribute to the relatively moderate cytotoxicity. Carboplatin is generally better tolerated than cisplatin [60] and in vivo studies could demonstrate the benefit of the carboplatin scaffold with

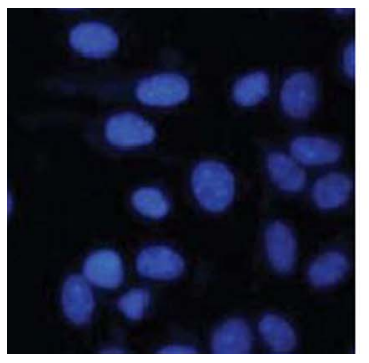

Ctr

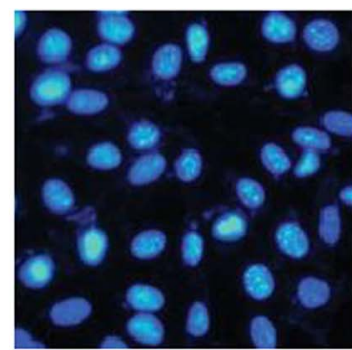

3

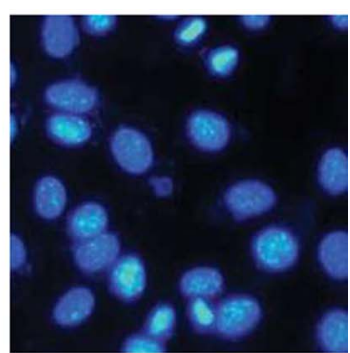

carboplatin
Fig. 5. Apoptosis induction. A431 cells were treated with $\mathrm{IC}_{50}$ concentrations of 3 and carboplatin for $48 \mathrm{~h}$ and stained with the fluorescent dye Hoechst 33258. Ctr $=$ untreated control. 
respect to cisplatin which, however, is beyond the aim of this paper.

\section{Acknowledgement}

A.A. acknowledges the Royal Embassy of Saudi Arabia Ministry of Education for a Saudi Arabia Government Scholarship. V.G. and C.M. acknowledge the University of Padova (grants 60A04-0443, 60A043189 and 60A04-4015/15, DOR2016).

\section{Appendix A. Supplementary data}

Supplementary data to this article can be found online at http://dx. doi.org/10.1016/j.jinorgbio.2017.09.009.

\section{References}

[1] T.C. Johnstone, K. Suntharalingam, S.J. Lippard, Chem. Rev. 116 (2016) 3436-3486 (and refs. therein).

[2] W.H. Ang, I. Khalaila, C.S. Allardyce, L. Juillerat-Jeanneret, P.J. Dyson, J. Am. Chem. Soc. 127 (2005) 1382-1383.

[3] L.J. Parker, L.C. Italiano, C.J. Morton, N.C. Hancock, D.B. Ascher, J.B. Aitken, H.H. Harris, P. Campomanes, U. Rothlisberger, A. De Luca, M. Lo Bello, W.H. Ang, P.J. Dyson, M.W. Parker, Chem. Eur. J. 17 (2011) 7806-7816.

[4] L. Ma, R. Ma, Y. Wang, X. Zhu, J. Zhang, H.C. Chan, X. Chen, W. Zhang, S.-K. Chiu, G. Zhu, Chem. Commun. 51 (2015) 6301-6304.

[5] R.K. Pathak, S. Marrache, J.H. Choi, T.B. Berding, S. Dhar, Angew. Chem. Int. Ed. 53 (2014) 1963-1967.

[6] Q. Cheng, H. Shi, H. Wang, Y. Min, J. Wang, Y. Liu, Chem. Commun. 50 (2014) 7427-7430.

[7] S. Dhar, S.J. Lippard, Proc. Natl. Acad. Sci. U. S. A. 106 (2009) 22199-22204.

[8] M.R. Reithofer, S.M. Valiahdi, M. Galanski, M.A. Jakupec, V.B. Arion, B.K. Keppler, Chem. Biodivers. 5 (2008) 2160-2170.

[9] K. Suntharalingam, Y. Song, S.J. Lippard, Chem. Commun. 50 (2014) 2465-2468.

[10] J. Ma, Q. Wang, X. Yang, W. Hao, Z. Huang, J. Zhang, X. Wang, P.G. Wang, Dalton Trans. 45 (2016) 11830-11838.

[11] Q. Wang, Z. Huang, J. Ma, X. Liu, L. Zhang, X. Wang, P.G. Wang, Dalton Trans. 45 (2016) 10366-10374.

[12] Z. Wang, Z. Xu, G. Zhu, Angew. Chem. Int. Ed. 55 (2016) 15564-15568.

[13] R.K. Pathak, S. Dhar, Chem. Eur. J. 22 (2016) 3029-3036.

[14] D. Tolan, V. Gandin, L. Morrison, A. El-Nahas, C. Marzano, D. Montagner, A. Erxleben, Sci Rep 6 (2016) 29367.

[15] D.S. Alberts, R.T. Dorr, Oncologist 3 (1998) 15-34.

[16] T.C. Johnstone, S.M. Alexander, J.J. Wilson, S.J. Lippard, Dalton Trans. 44 (2015) 119-129.

[17] H.P. Varbanov, M.A. Jakupec, A. Roller, F. Jensen, M. Galanski, B.K. Keppler, J. Med. Chem. 56 (2013) 330-344.

[18] S. Göschl, H.P. Varbanov, S. Theiner, M.A. Jakupec, M. Galanski, B.K. Keppler, J. Inorg. Biochem. 160 (2016) 264-274.

[19] J. Banfic, M.S. Adib-Razavi, M. Galanski, B.K. Keppler, Z. Anorg. Allg. Chem. 639 (2013) 1613-1620.

[20] Z. Xu, Z. Wang, S.-M. Yiu, G. Zhu, Dalton Trans. 44 (2015) 19918-19926.

[21] H. Song, H. Xiao, Y. Zhang, H. Cai, R. Wang, Y. Zheng, Y. Huang, Y. Li, Z. Xie, T. Liu, X. Jing, J. Mater. Chem. B 1 (2013) 762-772.

[22] M. Stiborová, T. Eckschlager, J. Poljaková, J. Hraběta, V. Adam, R. Kizek, E. Frei, Curr. Med. Chem. 19 (2012) 4218-4238.

[23] K.K.-W. To, W.-S. Tong, L.-W. Fu, Lung Cancer 103 (2017) 58-65.
[24] X. Zhang, M. Yashiro, J. Ren, K. Hirakawa, Oncol. Rep. 16 (2006) 563-568.

[25] O.A. Botrugno, F. Santoro, S. Minucci, Cancer Lett. 280 (2009) 134-144.

[26] K. Ozaki, F. Kishikawa, M. Tanaka, T. Sakamoto, S. Tanimura, M. Kohno, Cancer Sci. 99 (2008) 376-384.

[27] J.E. Shabason, P.J. Tofilon, K. Camphausen, Oncology 24 (2010) 180-185.

[28] G.R. Leggatt, B. Gabrielli, Immunol. Cell Biol. 90 (2011) 33-38.

[29] D. Griffith, M.P. Morgan, C.J. Marmion, Chem. Commun. (2009) 6735-6737.

[30] V. Brabec, D.M. Griffith, A. Kisova, H. Kostrhunova, L. Zerzankova, C.J. Marmion, J. Kasparkova, Mol. Pharm. 9 (2012) 1990-1999.

[31] J.P. Parker, H. Nimir, D.M. Griffith, B. Duff, A.J. Chubb, M.P. Brennan, M.P. Morgan, D.A. Egan, C.J. Marmion, J. Inorg. Biochem. 124 (2013) 70-77.

[32] D.M. Griffith, B. Duff, K.Y. Suponitsky, K. Kavanagh, M.P. Morgan, D. Egan, C.J. Marmion, J. Inorg. Biochem. 105 (2011) 793-799.

[33] V. Novohradsky, L. Zerzankova, J. Stepankova, O. Vrana, R. Raveendran, D. Gibson, J. Kasparkova, V. Brabec, J. Inorg. Biochem. 140 (2014) 72-79.

[34] V. Novohradsky, L. Zerzankova, J. Stepankova, O. Vrana, R. Raveendran, D. Gibson, J. Kasparkova, V. Brabec, Biochem. Pharmacol. 95 (2015) 133-144.

[35] J. Yang, X. Sun, W. Mao, M. Sui, J. Tang, Y. Shen, Mol. Pharm. 9 (2012) 2793-2800.

[36] M. Alessio, I. Zanellato, I. Bonarrigo, E. Gabano, M. Ravera, D. Osella, J. Inorg. Biochem. 129 (2013) 52-57.

[37] J. Kasparkova, H. Kostrhunova, O. Novakova, R. Krikavova, J. Vanco, Z. Travnicek, V. Brabec, Angew. Chem. Int. Ed. 54 (2015) 14478-14482.

[38] R. Raveendran, J.P. Braude, E. Wexselblatt, V. Novohradsky, O. Stuchlikova, V. Brabec, V. Gandin, D. Gibson, Chem. Sci. 7 (2016) 2381-2391.

[39] B.J. Harper, E. Petruzzella, R. Sirota, F.F. Faccioli, J.R. Aldrich-Wright, V. Gandin, D. Gibson, Dalton Trans. 46 (2017) 7005-7019.

[40] H.P. Varbanov, S.M. Valiahdi, C.R. Kowol, M.A. Jakupec, M. Galanski, B.K. Keppler, Dalton Trans. 41 (2012) 14404-14415.

[41] N.I. Ward, L.M. Dudding, Sci. Total Environ. 334 (2004) 457-463.

[42] J.D. Whiteley, F. Murray, Geochemistry: exploration, Environ. Anal. 5 (2005) 3-10.

[43] M. Crespo Alonso, A. Rigoldi, A. Ibba, L. Zicca, P. Deplano, M.L. Mercuri, P. Cocco, A. Serpe, Microchem. J. 122 (2015) 1-4.

[44] J.G. Morrison, P. White, S. McDougall, J.W. Firth, S.G. Woolfrey, M.A. Graham, D. Greenslade, J. Pharm. Biomed. Anal. 24 (2000) 1-10.

[45] OECD, Test No. 107: Partition Coefficient (n-Octanol/Water): Shake Flask Method; Organisation for Economic Co-operation and Development: Paris, (1995).

[46] J.J. Wilson, S.J. Lippard, Chem. Rev. 114 (2014) 4470-4495.

[47] R.A. Alderden, H.R. Mellor, S. Modok, M.D. Hall, S.R. Sutton, M.G. Newville, R. Callaghan, T.W. Hambley, J. Am. Chem. Soc. 129 (2007) 13400-13401.

[48] D. Montagner, S.Q. Yap, W.H. Ang, Angew. Chem. Int. Ed. 52 (2013) 11785-11789.

[49] L.E. Wedlock, M.R. Kilburn, R. Liu, J.A. Shaw, S.J. Berners-Price, N.P. Farrell, Chem. Commun. 49 (2013) 6944-6946.

[50] A.R. Timerbaev, S.S. Aleksenko, K. Polec-Pawlak, R. Ruzik, O. Semenova, C.G. Hartinger, S. Oszwaldowski, M. Galanski, M. Jarosz, B.K. Keppler, Electrophoresis 25 (2004) 1988-1995.

[51] M. Groessl, O. Zava, P.J. Dyson, Metallomics 3 (2011) 591-599.

[52] W.Q. Zhong, Q. Zhang, Y. Yan, S. Yue, B.L. Zhang, W.X. Tang, J. Inorg. Biochem. 66 (1997) 179-185.

[53] N. Graf, S.J. Lippard, Adv. Drug Deliv. Rev. 64 (2012) 993-1004.

[54] J.Z. Zhang, E. Wexselblatt, T.W. Hambley, D. Gibson, Chem. Commun. 48 (2012) $847-849$.

[55] D.Y.Q. Wong, C.H.F. Yeo, W.H. Ang, Angew. Chem. Int. Ed. 53 (2014) 6752-6756.

[56] E. Wexselblatt, D. Gibson, J. Inorg. Biochem. 117 (2012) 220-229.

[57] S.Q. Yap, C.F. Chin, A.H.H. Thng, Y.Y. Pang, H.K. Ho, W.H. Ang, ChemMedChem 12 (2017) 300-311.

[58] I.V. Tetko, H.P. Varbanov, M. Galanski, M. Talmaciu, J.A. Platts, M. Ravera, E. Gabano, J. Inorg. Biochem. 156 (2016) 1-13.

[59] J. Zajac, H. Kostrhunova, V. Novohradsky, O. Vrana, R. Raveendran, D. Gibson, J. Kasparkova, V. Brabec, J. Inorg. Biochem. 156 (2016) 88-97.

[60] G. Bouchard-Fortier, B. Rosen, I. Vyarvelska, M. Pasetka, A. Covens, L.T. Gien, R. Kupets, K. Pulman, S.E. Ferguson, D. Vicus, Gynecol. Oncol. 140 (2016) 36-41. 